\title{
ITALYAN MEKTEBI
}

Yazan: R. SALEILLES

Tercüme eden: Asistan Dr. Saim APAY

Klâsik mektebi, bütün nüanslariyle ve noktai nazar farklariyle tetkik edip klâsik sistemin gayri kâfi olduğu ve başka şeye ihtiyaç bulunduğu müşahede edilince onun yerine konmass teklif olunanın neden ibaret bulunduğunu tetkik etmek lüzumu kendiliğinden ortaya çıkar. İlmi ferdileştirme y Jllarnn acaba anti-klâsik modem sistemlerin getirdikleri yenilikler arasında bulamaz mıız? İște burada bunu tetkik edeceğiz. Zaten klâsik hukuki sistemin tam ve azimli bir rakib: olarak meydana çıkan yeni mekteb herkezce malûmdur. Bu mektep Italyan mektebi adı ve. rilen mektebdir.

Burada ltalyan mektebinin tam bir izahı yapılacak değildir. Filhakika burada doktrinleri gözden geçirilmesi mevzuu bahis de değildir. Italyan mektebinden, biz burada ferdileştirme fikri bakımından bilinmesi icab edenleri söylemekle iktifa edeceğiz.

Italyan mektebi adinm ilk anda, ve ceza felsefesinde vuku bulmus olan bu mühim cẹreyana tamamen yabancı kalmıs zihinleri sevkedebileceği bir hata vardır $\mathrm{ki}$, bunun üzerinde uzun boylu dưmaya değmez. Filhakika şuna işaret etmekle iktifa edelim ki, bu umumi tabirin, bir kaç istissa dı̧ında bütün modern Italyan Cezacılarmın fikirlerini ihtiva ettiği zannedilmemelidir. Italya'da, bidayetten beri, ve hâlâ da Carara gibi en mॄşhurlanm zikretmekle iktifa ediyorum. Büyük cezacilarm mensub bulundukları, gayet parlak bir klâsik mektep mevcut olmuştur. Yine unutmamak icab eder ki Rossi de aslen Italyandur. Ve şununda ilâve edilmesi icab ederki, Beccaria'dan beri, Italya, Ceza hukuku sahasındaki ilim cereyanlannm daima başında gelmiş̧tir. Hattâ zannediyorum ki asrnndan daima biraz önce gitmiştir. Beccaria ile, asirndan önce tamamiyle mücerret ve objektif bir mekteb olan, klâsik mektebin temellerini atmıştır; bu tarih suç ve cezalann keyfiliğinin ve sığınabilecek tek teminatm herkeze şamil ve herkes için müsavi şekil de tatbik edilecek bir kanun kaidesinde aranmak lâzım geldiği kanaatìn uyandırdığı zamana rastlar. Daha sonra, Rossinin zamanında, Italyan Universitelerinin şöhretini temin eden 
hocaları sayesinde, néo-klâsik mektebin mümeyyiz vash olarak telâkki edilebilecek olan, cezai mesuliyette ferdileştirme yolundaki geniş hareketin hakiki muharriki olmuştur. Nihayet bilináiği, ve görüleceği gibi, nerede ise 30 seneden beridir italya yeni bir reformun, hepsinden daha radikal bir reformun tohumunu atmış bulunınaktadır.

Klâsik Italyan mektebi hakkında, son bir noktaya daha işaret edelim. Yalnız ve yalnız bu mektepdir ki 1889 tarihli yeni Italyan Ceza kanununa vücut vermiştir.

Bu kanun, ned-klâsik mektep adı verilebilecek mektebin en mükemmel bir nümunesi olarak kabul edilmek icab eder. Hukuki muhteva ve şekil bakımından bu kanun en dikkate şayan hukukî abidelerden biri olup, o zamana kadar görülmemiş derecede ince nüans ve teferruat arzetmekte, vakkialan derinden derine tahlil etmekte en küçük teferruata kadar inip her şeyi derrpiş etmiş olmağa çalı̧̧maktadır.

Kanun hâkimin yerini almakta, ferdileşmeğe ihtiyaç gösterecek bütün halleri evvelden hissetmek ve keşfetmek ve uygưn olan hal tarzınu kend:si tesbit etmek istemektedir. Adetâ, münferit ferdileștirilmiṣ hâ diselerin bir kataloğu bahis mevzu'udur. Yargıca düșen iş her vak'a karşısında Kanunu açı, hakkında hüküm vereceği meselenin hangi maddeye girdiğini tayinden ibarettir. Bu madde bulununca, mesele kalmamaktadır, hal tarzı derpiş edilmiștir: bunu okuyup tadbik edecektir.

$\mathrm{Bu}$ eser bitmez tükenmez bir hazinedir. Fakat maalesef bu kanun geçmiş bir devrin kalıntısı olup, doğmakta olan yeni devrin habercisi değildir, kanuni bir mevzu'at için ise bundan daha büyük bir mahzur olamaz. Bir sistemi tedvin için onun ilminin yapılmıs olmasını beklersek, tarihi bir eserden, geçmişteki çalışmaları mükemmel bir surette hülâsa etmekle beraber, teşekkül etmekte olan yeni telâkkilere tetabuk etmeyên ilmî bir çalışmadan baska bir şey yapmamıs olmak tehlikesine maruz ká lynz. Kanunlar, aralıklar ve boṣluklar arzetmek tehlikesini göze olarak, herhangi bir sistemin, halkın șuuruna nüfuz etmeve başladıkları zamanda hazırlanmalıdırlar ki, doğmakta olan doktrinlerin tatbik ve inșa. asına yol gösterebilsinler. Yok eğer, Kanunlar temsil ettikleri méíktebin tekâmül ettiği ve bilhassa dağılıp parçalanmakta olduğu bir sırada vücude getirilecek olurlarsa hayata uygunlukları ve onunla bir ilişiklikleri kalmamıs olacaktır ki kanuni bir mevzuat için en büyük mahzur budur. Bu tehlikenin, hem yeni ltalyan Ceza Kanunu ve hem de eğer esasl bir șekilde yeni baştan gözdengeçirilmekte acele edilmez ise- Fransız Ceza Kanununun tadil projesini pek yakın bir gelece'cte tehdit etmesinden endișe 
etmek pek yersiz olmaz. Isste Italyan klâsik mektebinin hukuki tecritlerde ifrata kaçması yeni bir mektebin, meydana çımasına başka bir vasıl izafe edilmeksizin, sadece Italyan mektebi adı ile anılan mektebin doğmasına yol açmıștır.,

Filhakika 1875 senelerine doğru Italyada (Lombrosonun "Uomo delinquente" sinin ilk tab'ı 1876 senesinde yapılmıştır) fevkalâde mühim ilmi bir cereyan baş göstermiştir. Bu cereyanın doğuşunda, umumiyel itbariyle, muhtelif pozitivist mekteblerin rolü olmakla beraber, o zamanlarda nisbeten yeni sayılan iki ilim kolunun, Antropoloji ve sosyolojinin bilhassa tesiri olmuştur. Nitekim bunun içindir ki bu yeni Italyan mektebine bazen pozitivist mektep, bazen de antropolojik mekteb ismi verilmekte ve suya sabuna dokunmayan bir tabir olduğu için de bu mektebe Umumiyetle Italyan mektebi denmektedir. Fakat bu tabirin ne mânaya geldiği malûm bulunmaktadır.

Denilebilir ki bu Italyan mektebi -ki en meşhur mümessilleri Lombroso, Ferri, Garofalo, Sighele'dir - ilk önce klâsik tarzda anlaşılan "irade muhtariyeti" tezine karşı bir reaksiyon olarak ortaya çıkmıștır. Suç, ira de muhtariyetinin bir tezahürü olarak telâkki edilmiștir. Italyan mektebi ise suça tabii bír hâdise gözüyle bakmakta, onun münhasıran tabii fak. törlerin mahsulü olduğu ve irade muhtariyeti fikrine hiç bir yer bırakmadığını düşünmektedir. Lombroşo'ya göre bu faktörlếr hemen hemen münhasıran antropolojik mahiyette faktörlerdir. Ferriye göre ise, daha ziyade sosyolojik mahiyettedirler; bununla beraber bu nokta ehemmiyeti haiz değildir ${ }^{1}$. Suç ister atavistik şidtlardan ileri getsin, ister münhasuran içtimai mahiyette faktörlerin (meselà içtimai muhitin, hemen hemen mukadder tesirinin, ekonomik şartlann, muhitteki sefaletin veya daha ziyade vaki olacağı gibi, gittikçe artan lüksün ve bunun, Tarde'in tabiriyle taklid yoluyla Cemiyetteki en aşağı tabakalara vainncaya kadar nüluz eden ifsat edici tesirinin) neticesi olsun, irade muhtariyeti fikinini tamamiyle bertaraf etmeyi gerektiren tabii mahiyette bir takım vakıalarn zaruri bir neticesiditr.

Görülüyor ki mebdede Ferri ile Lombroso arasında mevcut bulunan ihtilâflar, hiç değilse, suçun, bizatihi nazara alındıkta, mahiyetinin ne olduğu hususunda pek ufak bir ehemmiyet żrzetmektedir. Suç, her ikisi için* de münhasıran tabii bir olaydır. Ve harbin kitleler bakımında oynadığı role benzer içtimai bir rol oynất, Harp cemiyette suç ise ferdler arasında bir elimination yapar. Harb için olduğu gibi, suç içinde buna vücut veren

1) Ferri, Sơciologie criminellê, yine Bk. Vaccoro, Genesi e funzione delle leggi penali. 
psikolojik veya sosyolojik esas ve temayülleri ortadan kaldırmak değil, ancak bunları başka istikamete yöneltmek kabildir.

Buna mukabil, sistemin pratik neticeleri ve Kriminolojide ne gib: reformların yapılması gerektiği bakımından Ferri ile Lombrozonun noktai nazarların birbirinden tefrik etmek fevkalâde mühimdir. Filhakika Italyan mektebi evvelâ müsbet. bir veçhe arzetmekle beraber, yani felsefi ve ilmi bir takım fikirlèr ileri sürmekle, menfi bir cephede arzetmekte, yani hâkim bulunan mektebin eseri olduḡu zannedilen neticelerin bir tenkidini de teşkil etmektedir. $O$ zamandan beri pek ya. yılmı bir tabirle, İtalyan mektebinin meydana çıktığı siralarda tered. dütsüz denilmekte idi ki, vardığı neticeler bakımından o devrin mektebi, tam bir iflâs halinde idi.

Asla Klasik Mektebinki kadar yüksek bir başlangıçtan hareketle bu kadar düşük neticeler elde edilmemiştir. Büyük spiritualist cezacıların (ezcümle Rossi gibi) tesiri ile ceza hukuku insanileştirilmiş, yükseltilmiş, bir nevi ruhanileştirilmişti. Insamın muhtariyeti fikrinden hareket ediliyor ve fakat ayni zamanda bu muhtariyet her suçluda ayrı ayrı tesbit ve analiz. ediliyordu. Sanksiyon fikri, adalet fikrini tatmin etmiş olmak maksadiyle, muhafaza ediliyor, fakat ayni zamanda, yerinde bir eklektizmle, Cezí Cemiyetin müdafaası için bir vasıta olarak telâkki edilmeye başlanıyordu. bu suretle mutlak adalet fikrinin icablan, hemde Cemiyetin lâzimeleri yer alyyordu. Ceza, hukuku şahikasına varmıș görünüyordu; tabii rukukun revaçta bulunduğu bir devirde, tabii hukukun, Ceza hukuku sahasında hakiki müspet itadesini bulmuş olması ile iftihalr edilebilirdi. Bu nunla beraber, varılan neticelere bir göz atılacak olursa görülürki suçluluk asla bu zamanda olduğu kadar yüksek olmamıştır. Suçluluk dalgası her yeni istatistikte daha çok kabaryordu; sanki adalet müdahalesini arttırdıkça ve yerini buldukça, suçlulukta artıp yükseliyordu. Cezanın, bizatihi cezanın suçluluğun asıl âmilinin teşkil etmeğe başladı̆gna ve ceza hukukunun suçun artışına yardım ettiğine ihtimal verilebilirdi.

Nitekim suçluluğun suçta tekarrür dolayısiyle artmış olması buna delil teşkil ediyordu. Suçlar münhasıran değilse bile ekseriyai mükerrirler tarafından işleniyordu; daha doğru söylemek icab ederse genç çocuklar ve mükerrirler tarafindan işleniyordu. Fakat netice ayni kapıya gelmez mi? Genç çocuklann ișledikleri suçlar hakkmda ekseriya beraat karan verilmekte ve bu gençler islâhhaneye yollanmaktadır; rüşt yaşında tekrar haklannda bir mahkûmiyet karan verilince, resmi istatistikler, Kanun gözünde olduğu gibi, ilk defa suç işleyen kimseler olarak göstermektedir. Hakikatte ise, bunlar Devlet lslâh evlerinden (Colonie d'Etat) çkan ve. 
infaz sitemimizin kıymeti hakkında fikir verebilecek bir tecrübeyi heł nüz geçirniş birer mükerrir olup bu sistemin verdiği neticeleri ve dolaynsiyle haiz olduğu değeri isbat etmektedirler. Sü̈phesiz denilebilir ki biz gençler küçük yaşlanndan beri o kadar bozulmuşlardır ki hakikatte her hangi bir infaz sistemi, ne de her hangi bir islâh sistemi bunlara kâr edebilir. Kabahat kendilerinin, kendi tabiatlarınun olup, infaz rejiminin değildir. Fakat bu sekilde Lombnozo ve Ferririnin fikirlerine gelin. miş olmaktadır; bu takdirde bunlaı un ya birer doğuştan suçlu yahutta is-lâhı kabil olmayan birer suçlu olduklan kabul edilmiş olmaktadır. Mes'.uliyet ve muhtariyete ve bunun neticesi olarak, manevi serbesti sayesinde iyileşmenin kabil olunduğuna inananlann ise bu fikri kabul etmelerine im-kân yoktur. Şu anda hakkında bir hükme varmağa çalıştığımız mektep ise: tamamen bu serbesti fikrine istinad etmektedir. Görülüyor ki hangi taraftan tutulmak istenirse istensin, bu mektep ve başvurduğu hukukî esaslar iflâs etmektedir.

Kaldı ki, gençlerin işaret ettiğimiz geniş mânadaki mükerrerliklerínin yan başında, istatistiklerde asıl ehemmiyetli yeri büyük mükerrirler yan: haklanndaki birinci mahkûmiyet reşit olduktan sonra vaki olmuș suçlular işgal etmektedir. -Demek oluyar ki, tekerrür ister küçüklerde olsun ister büyüklerde olsun, ister vilâyet ceza evleri bahis mevzu'u olsun: ister infaz kolonileri mevzubahis olsun, kelimenin geniş mânasında hapsin hapsi doğurduğundan bahsedilebilecek bir durum mevcut bulunuyor-du. llk defa suç işliyyenlerin sayısındaki artış, her şeyden önce ıçtimai şartların anormal olduğuna ve umumî ahlâkın sükut etmekte bulunduğuna delâlet eder; günümüzde de durum böyledir. Fakat eğer mükerrirlerin sayısında da bir artı̊s mevcut bulunuyorsa, bu "ceza" müessesesinin de tena bir şekilde işlemekte olduğuna delâlet eder. Ceza suçu önleyeceğine: fazlalaştırmaktadır. Fertte gizli ve virtuel halde bulunan suçluluğu ortadan kaldıracak verde, bunu bir nevi inkişâf ettirmektedir ve bunu insandaki şeref hissini, ahlâkın en kuvvetli siperlerinden ve hattâ pek cok dürüsı insanlar için, ahlâklhhklarının tek dayanacağı olarak kalan gurur duygusunu yok etmek suretiyle, geliştirmektedir.

Demek ki, ağaca meyvelerine göre bir kıymet takdir etmek icab. edecek olursa, klâsik mektep daha başlangıçta muvaffakiyetsizliğe mah. kûm edilm:s bulunuyordu. Gerçi buna şu şekilde bir cevap verilmek istenmiştir. Kabahat bu ceza sisteminin ne hukukan yanlıs olduğundan nede bu sistemin mahkemelerce yanlı̧ tadbikinden ileri gelmemektedir; kusur cezamın yanlıs şekilde infazından ileri gelmektedir; hukukî mektep ancak kendi eseri olan kanun'dan ve hâkimlerinin bunu tadbikinden so- 
rumlu tutulabilir. Yoksa infaz sisteminin bozuk oluşundan değil. Kabahat ceza Kanununda değildir, hâkim veya jürilerde ise hiç değildir. Cezanın infazı şekli kusurluduır. Filhakika tekerrüre sebep olan şey, hapishanenin mümkün kıldığı fena temaslar, bir arada infaz rejiminin ifsat edici tesirı ve insanlarıa ne kadar fena huy varsa bir araya getirilmesi keyfiyetidir. İlk defa suç işleyip bu muhite yeni giren ve oradakilerle arkadaş olmak suretiyle, fenalar arasından en feması ile bir olan yeni mahkûm, ister iste mez, içinde kalmış olan son ahlâki duyguları da kaybedecektir. Hislerimizin, hareketlerimize tesir edebilecek bir kuvvet olarak kalabilmeleri ancak, bunlarn muhitten bir t€şvik görmeleri ile mümkündür. Hislerimize hayat veren şeyler içimizden geldiği kadar dışımızdaln da gelmektedir. Bir diş tesirin gerrek mensup bulunduğumuz içtimaî muhitin, gerekse içimizdekini inaçlar için olduğu ggibi, tabiat ötesi muhitin, bunları bizde doğurması lâzımdır. Daimì bir temas ve tesir lâzımdır. Bezulmus kimselerle bir arada yaşayan insan da yavaş yavaş onların karakterine bürünecektir; bunun mukadder bir netice olduğu söylenebilir. Fakat dahası da var: Ahlâk duygusunu ayaikta tutan şey, hatta bu duygunun mevcudiyeti süpheli bir hal arzeden hallerde bunun asıl dayanağı, șeref ve gurur hissidir; halbuki bu melhumlar da yine içt mai hayatın ortaya çıardığı mef. humlardır.

Filhakika bu mefhumlar çok geniş bir topluluğa mensub bulunan bir insanın cemiyet üyesi olduğu, ve bu cemiyet tarafından kabul edilmis ve onun tarafindan sayllyyor, bulunduğuna dair bir hissin neticesidir. Insan kendisini tecrid edilmiș hissetmemektedir. Bir organizmaya mensub olduğunu ve onun müşterek şuurunu aksettirdiğini hissetmektedir; bunun aksine bir his s:zi cemiyete karşı cephe almaya götürecektir. Ceza ise, ona atfetmekte olduğumuz terzil edici hassaları dolayısiyle mahkûmu dürüst insanlar topluluğundan çkanp, diğerlerinin cemiyetine sokacaktır. Onu şerefsiz ve lekeli bir insan yapmakta ve dolayısiyle, düzgün içtimai hayattan onu tecrid edip yalnız bırakmaktadır. Fena bir kimse olmainış bulunsa ve hatta hapishanede etrafının fena tesirlerine mukavemet etmiş olsa dahi, hapishane onu dürüst insanların topluluğundan seklen olsun dıșarı çkarmıştır. Hap̣ishanenin, onun için bundan böyle mümkün kıldığı tek içtimaì hayat, cemiyetin dışına atılmış kimselerin teşkil ettiği ve sosyolojik bakımdan kendisine gëre bir teşkilâtı bulunan toplulukta yaşamaktadır. Artık onlardan olmuştur, ve onlardan geri kalmaması icin sebep yoktur. Iște mükerrerliği bu șekilde izah etmişlerdir. Kabahat, C.K. unun hukuki yapısında ve klâsik mektepte değil, cezanın infazındai ve bilhassa hapishanelerde mahkûmları bir arada bulundurmaktadır. 
Bunun üzerine bu mahzuru önlemek maksadiyle, infazcıllk mektebi adı verilen şayanı takdir mektep teşekkül etmiştir. Bu mektebin ilk tesirleri Fransa'da görülmemisse bile, belki en büyük temsilcileri Fransa' da çımmışıır. Bu mektep her tarafta ve bilhassai hâkimler arasında büyük bir rağbet görmüştür. Adliye teşkilâtı ile ilgili olanların intaz meselesi ile, bu sahada yapılması gerekli islâhat ile ne kadar alâkaidar olduklan bu mektebin ne kadar geniş bir merhamet ve insaniyet cereyanına yol açmış olduğu Fransa'da lâyıkiyle bilinmektedir. Herkez öyle bir gayret, öyle bir inanç ve islâhat arzusu ile işe koyulmuştur ki bu çalışma ne kadar takdir edilse yeridir. Bu mekteptirki her tarafta infazcllk kongreleri ile patironaj kongreleri tertib edilmesine ve bu suretle, tabir caiz ise ilmi düşünce cereyanlarının evrenselleşmesine ve arzu edilen islâhatın icrasının tesriine sebep olmuştur. Nihayet yine bu mekteptirki bizde de, bir nevi daimi infazcılık kongresi teşkil eden aktuel meseleleri günü gününe tetkik ve ceza ırejimlerinin islâhı için her türlü imkâna baş vurmayı kendisine mevzu ittihaz etmiş bulunan "ceza evleri Genel Kurumu” nun teşekkülüne sebep olnuş̧tur. Bu kurum, yayınladığ bülten ile vanlan neticeleri tesbit ve ahaliye duyurmaktadır. Toplantılanndaki münakaşalann vüsati sayesinde her türlü meseleyi inceden inceye tahlil ve tetkik etmekte ve bunlairın kanunlaşmalarına yardım etmektedir. Sadece Fransa'da değil ceza ilmi ile iştigal olunan her yerde bu kurumun yapmış olduğu tàzmetlerin haddi hesabı yoktur. Avrupa'da son zamanlarda hazırlanmış hiç bir ceza kamunu yoktur ki muhtemelen kaynaklanndan ekserisini Firansız infazcılık mecmuası isimli neşriyattan almamış olsun. Bu mühim infazcılık mektebinin takib etmiş ve halj hazırda da takip etmekte olduğu gayelere gelince, bunlan ikiye irca etmek mümkündür. Bürincisi, cezanın infazı sırasında, mahkûmun tecrid edilmesini temin etmek ve bu suiretle diğer mahkûmlarla temas neticesinde ifsat edilmesine mani olụ̣ islâhını kolaylaştırmak; ikincisi mahkûmun cezasını çekip bitirdikten sonra cemiyet içinde yeniden kendisine bir mevki yapabilmesini mümkün kılmak suretiyle, cezanın kendisini aralanndan cekip çıardığı namuslu vatandaşlaı arasına eski mahkûmun tekrar girmesini ve bu muhite yeniden intibak edip kendisine bir iş muhiti edinmesini ve namuslu, muntazam bir hayat sürmesini sağlamak.

O halde netice olarak, deniyordu ki, cezamı tabi olduğu hukuki sistemi değiştirmeğe lüzum yoktur. Bunun tabi bulunduğu idarî sistem islâłła muhtaçtrr. Ceza kanununa ve hele ceza hukukuna dokunmayalım. Sadece cezanın infaz tarżnı değiştirelim.

Bununla beraber âşikâr bir hakikattir ki, cezanm infaz tarzının do ğiştirilmesinden bir fayda hasıl olabilmesi isteniyorsa, idari bir islâhatla 
ıktifa etmek mümkün değildir. Çünkü cezaların nasıl infaz edileceği känunda tarif edilmiş bulunmaktadır. Bu it:barla, bu bakımdan olsun, ce. za Kanun'unun tâdili icab etmektedir. Fakat acaba bu Kanunun br kac maddesinin tâdili ile iktifa etmek kâfi gelecek midir? Yoksa asıl değiștirilmesi icab eden kanundaki infaz sisteminin istinad ettiği temel prensib midir? Bizzat "Infazcilk" ismi verilen ceryan, bu sonuncunun, daha muhtemel olduğunu göstermektedir.

Zira infazcıllk mektebinin ortaya attığı prensiptirki yalnız cezaların infaz rejiminin değil, eninde sonunda cezanın adli ferdileştirilmesi sisteminin de kabulünüi icab ettiriyordu.

Bu hal infazcllk Mektebinin, İtalyan mektebi tarafindan ileri sürülen fikirleri benimsemiş olduğuna açıca delâlet etmez mi? :3öyle bir düşünce yanlış olur, ve infazclik mektebi de kendisine bunun atfolunmasım çok haksızca bulacaktır. Fakat, yine de ikisinin muayyen bir ölçüde olsun bi:leştikleri bir hakikattir; infazcllı mektebi istemeden, diğerin yolunu açmıștır.

İște üzerinde durulmas!̣ istenilen enteresan husus, iki mektebin surf zahiren dahi olsa muazzam bir parodoks teşkil eden, bu birleşme noktasidir.

Filhakika şüphe yoktur ki infazcllk mekteb:n fikirlerinin esasın mahkûmun k€ndine has karakterinin göz önüne almaması teşkil eder. Mahkûm hakkında bir ceza hükmed:Idiği andan itibaren, işlemiş olduğu suçun unutulmast ve ona işlemiş olduğu suça göre değil, insan olarak nasılsa ve nast b:r değer arzediyorsa ona göre muamele eçilmesi icab edecektir. Ve zaten, böyle olmaksızın. suçlunun islâhı kabil değildir. Halbuki her is'âh ameliyesi iki veçhe arzeder: bir menfi bir de müsbet veçhe. Birincısi tamamen tedafuii olup, ferdin fena tesirlerden masun bulundurulmasm tazammun eder, müsbet veche ise tamamen inşai bir mahiyet arzedip ferde yepyeni bir karakter verilmesi gayesini güdeir. Bu itibarla cezanın, islâh ame! isini suçlunun karakterine uydurmaktan ibaret olması icab eder. Filhakika terbiyeyi mümkün kılmak isteniyorsa baş vurulan tedbirlerin bu tedbirlere mevzu teşkil eden kimsenin tabiatına tam tamamına uyması gerektir.

Bununla beraber buna dayanarak infazcllk mektebinin muhakkak surelte hücrecilik mektebine müncer olduğu neticesine varılmamalıdır. Filhakika tecrid, korunma tedbiri olarak kesin ve eskiden beri baş vurulan bir tedbir olmakla beraber, terbiye tedbiri slarak tamamiyle kifayetsiz bir tedbirdir. Eğger ceza ile terbiyeden maksat, ilgili kimseyi ilaride 
muhitinin ve hayatın onun üzerinde hasıl edeceği fena tesirlerle mücadele edebilecek hale getirmek ise itiraf etmek icab ederki onu içtimai hayattan tamamen tecrit etmek ve her türlü fena tesirden masun bulundurmak, elde edilmek istenen bu netice ile mütenakız bilr tedbirdir. Eğer bir organa vücut veren veya hiç olmazsa onun șeklini tayin eden bu organun gördüğü vazife ise, bir organ bu vazifeyi görmeğe alıştırmak için işleyecek halden çıarmak hakikaten kabili izah bir şey değildir. Bu itibar. la birçok kriminalistler ve bilhassa Ingiliz mektebi mensuplan, hücrenin uzun müiddetli cezalarda pek talî bir rolü olması gerektiği, bu rolün ferd, vicdanıyla karşı karşıya bırakıp bir müddet onu yaptıklan üzerinde ken di kendine düşünmeye sevketmekten ibaret olduğu fikrindedirler. Bu hususta ifrata kaçmamak lâzımdır. Mahkûm yeni bir ruh ve karaktere sahip olmaya başlar başlamaz onu faaliyete geçirmek ve bir takım tedbirlexi aldıktan sonra müşterek infaz rejïminden korkmamak lâzımdır. Mahkûmun yeniden hayat ve b:lhassa ahlâk mücadelesine katılabilecek hale gelmesi lâzımdır. Bir ceza rejiminin imkâr verdiği nisbette, mahdutta olsa' onu, müteşebbis kılmaktan çekinmemelidir. Şüphesiz, alınacak tedbirler meselesi kahyor. Fakat bu meselenin de, suçlunun iyi haline ve eldc edilen neticelere göre birinden diğerine geçilecek devreler tesisi ve islâh oldukları düşünülenlerin cezanın bitmesinden evvel, hiç değilse şartla, serbest burakılmalanna kadar gidecek tedrici bir serbesti sistemiyle halled;leceği zannedilmekte veya hiç değilse ümid edilmektedir. Suçlu tedricen muhtelif tecrübelere tabi tutulmaktadır. Bu sistemin esasın Avustralya infaz kolonisinde bulmak miümkündür. Bu esas bilhassa Walter Crofton tarafindan müdafaa ve tavsiye edilmiş ve evvelâ Irlandaida tadbik olunmuştur. Sonradan Müterakki Sistem adı ile Ingiliz infaz sistemi haline gelmiştir. Memleketimiz gibi, uzun müddetli cezalarda hücre rejimini kabul etmemis bulunan memleketlerde bu tedrici serbesti sistemi daha faydalı görülmekte ve kısmer olsun tatbik edilmektedir. Meselâ bizde, müstemlekeler de infaz edilen cezaletrda, aşağı yukan bu sistem tadbik edilmektedir. Ağır hapis cezasının müstemlekelerde infazma müteallik 1854 tarihli Fransız kanunda esas itibariyle Ingiliz müterakki sistemi kabui edilmiş bulunmaktadır. Bu suretle cezanın mahkûmda kaydedilen terakkiye uydurulması yolunda, iptidai olmakla beraber ilk adım atılmıs bulunmaktadir.

Ağır hapis cezasında jptidai ve sathîi bir tarzda tatbik edilen bu esasın bugün mükerr:melleştirilmesi ve genişletilmesi istenmektedir. Ayni sistemin merkez ceza evlerimizde de cari olması temenni edilmektedir. Hattâ M. Leveille, tarafindan bunun Afrika birlikleri adı verilen ve evvelce 
muayyen bazı mahkûmiyetlere uğraimış olupta Afrikaya gönderilen kimselerden teşkil edilen askerî birliklere tatbiki istenmiştir. Fikir tatbikat güçlükleiri arzetmekle beraber, açk bir hakikat ihtiva etmektečir. Bu hakikat mahkùmlan ahlâklılık derecesine göre sınfflara veya guruplara ayırmak keyfiyetidir. Bu suretle cezanın tatbikinde geniş ölçüde bir müsavat sağlanacağı şüphesizdir. Böyle bîr müsavat ise büyük faydalar temin edeceği gibi insanì ve adalete de tamamiyle uygundur. Bununla beraber, bu müsavaat sağlanırken işlenmiş olan suçun ve içtimai ehemmiyetinin nazara alınmadığı ve sadece ferdin ahlâki deḡerine ve islâh olma ihtimaline ehemmiyet verildiği de gizlenmemelidir.

Süphesz meselenin başka bir hale getirildiğine ve başka meselelerle karıștınldığına ihtimal verilebilir. Yukanda bahsedilen ferdileștirme sadece cezanın infazı sırasında ve mahkûmun islâhı müșahede edildikçe tad. bik edilecektir; mahkûmun iyi hali için verilen bir prim, onu kendisinden beklenen şeylere teșvik ve dolayısiyle ahlâken düzelmesine yardım çarelerinden biri mevzu'u bahistir. Bunun, mahkûmiyet hükmünde cezanın suça göire değil, suçluya göre seçilmesi suretiyle temin olunacak adli bir ferdileștirme ile hiç bir alâkası yoktur. Burada, daha başlangıçta, henüz infaz makaniları kendisine teslim edilen şahsın değeri hakkında bir fikir edinmeden vaki olacak bir sınflandırma da bahis mevzu'u deḡildir; buradal sözü geçen şey, sonradan cezanın infazı sırasında ve suçluda müşahede edilen iyi hale istinaden yapulacak bir sinıllandırmadır. Bu hal. cezaların bir ve müsavi olması prensibine, ancak vasıtalı bir surette tesir edebilir; zira iyi hal için prim mevzu bahis ise herkes bunu hakedip taleb edebilir; bu umumiyetle tadbik edilen ceza rejiminin bir rüknünü teşkil etmektedir. Ceza hukukumuzun temellerinden biri olan cezada eşitlik firensibi ihlâl edilmiș değildir; sonradan, cezanın infazı sırasında ve mahkûmun iyi haline istinaden, tedricen sinflama suretiyle vaki olan bir ferdileştirme, prensibe bir istisna teşkil edecek mahiyette değildir.

Fakat infazcılhk mektebi cezanın infazı sırasında vaki olan ve baş. langıçta, aynı cezaya mahkûm olmuş bütün mahkûmlann bir arada bir mï̈ddet bulundurulmasını tazannum eden bu ferdileştirme ile iktifa etmeyecektir. Mahkûmlainn başlangıçta bir arada geçirecekleri devre, içinde bir nebze ahlâk duygusu kalmış kimseleri ve bir şaşkınlık eseri olarak suç işlemis namuslu kimseleri-ki böylelerine raslanabileceği bir hakikattir- en fena tesirleire maruz bırakmak suretiyle ifsat etmeğe kâfi gelecektir.

Görülüyorki infazcsllk mektebinin, vazettiği prensiplerin mantıki bir neticesi olarak, daha ileri gitmesi ve hücreye koymak suretiyle tecrid yerine veya hiç değilse bununla birlikte, daha başlangıçta bir sımıflandırma yapılmasın istemesi icab ediyordu. 
Nitekim meselâ muhtelif mahkûmları aynı ceza evinde koğuşlara ayracak yerde, böyle biir ayırma asla mutlak bir ayırma teşkil etmeyeceği cihłetle her ceza evinin bir kategori mahkûma tahsisi lüzumu ileri sürülmüştür. Bu suretle, mahkûm cezanın başlangıcından itibaren, valziyete göre, şu veya bu ceza müessesesine gönderilerrek, kendisine mümasil, yani aşağı yukan ayni ahlâk seviyesindeki kimselerin bulunduğu şu veya bu guruba dahil edilmiş olakcaktır.

¡Hücre usulünün kısmen tadbikine müteallik 1875 tarihli kanunumuz, ezcümle, bir sene bir günden fazla bir mahkûmiyeti olanlar için, yani bizarur mo'kez ceza evlerinde birlikte infaz usulüne tabi olacak kimseler için, cezada bir tebeddülât yapılması inikânını, bu kimselere cezanın infaz usulünün değiştirilmesini istemek hakkını, vermektedir; bu kimseler cezanın infazına başlanaca ğı sırada, cezalannın hücrede infazını isteyebilirler. Yukanda sözü geçen Afrika birlikleninin teşkilâtına dair olan projesinde $\mathrm{N}$. Léveille, bazı hapis cezass mahkûmlarının da istedikleri takdirde hapis müddetleri yerine bu müddetin iki veya üç mislini kolonilerde askeri hizmetle geçirebilmelerini ve cemiyete karşı olan borçlannı bu şekilde ödeyip yeniden cemiyet girebilecek hale gelmelerini teklif ediyordu. Bütün bunlar, cezanın, daha başlangıcından itibaren ferdilę̧tirilmesi tedbirlerinden başka başka bir şey midir? Mahkûmlar daha başlangıçtan itibaren, adli yol ile değil de idari yoldan, muhtelif guruplara. ayminaktadirlar.

Hattâ, mükerrirlerin deniz aşın kolonilerde sürülmesine (relégationn) müteallik 1885 tarihli Kanunun tadbikatında bile ayn şeye rastlanmakta değil midir? Kolonilerde iki türlü ikamet mecburiyeti (relagation) mevcuttur. Biri kolonide infaz edilen hakiki bir ceza rejimi teşkil etmektedir. Diğerinde ise kolonide ikamete mecbur edilmiş kimse (relégué) Kolonide serbest veya yarı serbest bir halde bulunmaktadır. Aslì cezasını çekip bitirdikten sonral kolonilerde ikâmete mecbur olan kimsenin bu iki ikamet rejiminden hangisine tâbi olacağını ise, Pariste bir komisyon, mahkûmun irtikâb etmiş olduğu fiili nazara almaksızın tayin etmektedir.

Görülüyor ki, cezans infaz sırasında: mahkûmun arzettiği duruma göre ferdileştíilmesi yerine mahikûmun şahsına bakarak daha başlangıçtan itibaren ferdileştirilmesine doğru gittikçe artan bir temayül mevcut olup daha bidayette, duruşma bitipte hükmün tesiri henüz kaybolmamış iken mahkûmun, karakterine, muhitine, geçmişine bakarak ona uygưn bir ceza rejimi tadbik edilmektedir. 
Yalnız bugün bu iş, idari yoldan ve ne adli ne kanuni hiç bir teminat bulunmaksızın yapılmaktadır. Böyle olunca, cezanın bașlangıçtan itibaren ferdileştirilmesi ișinin hâkime brakılmaması ve hâk:min bunu soruștur. mada toplanmış malûmata dayanarak ve durusmada edindiği intibaa göre, aleni olarak ve dolayıs:yle alâkalı için büyük bir teminat mevcut oldu gu halde, yacmaması için ne sebeb mevcut olabilir?

$\mathrm{Bu}$ ferdilesme idarî yollárla yapıldığı takdirde bir cok tehlikeler s. zetmesi ihtimali mevcut değil midir?

Görülïyor ki infazcllsk mektebinin esast, mahiyeti itibariyle, bizarur, münhasıran :ka edilmiş bulunan suçun nazara alınması keyfiyetinin ye. rine suçlunun şahsının nazara alınması keyfiyetinin geçmesi neticesini doğurmaktadır. Italyan mektebinin istediği ise bundan başka bisșey değildir. Geride bir nokta kalıyor ki, o da bunu ne şekilde istediği, ve onun istediği șeklin şayanı kabul olup olmadığıdır.

Fakat bunu tetkike başlamadan evvel, varmış olduğumuz neticeleri bir hülâsa edelim.

Dedik ki, vardı̆gı neticeler itibariyle klâsik mektebin yıkılmaya mah. kûm olduğu görülüyordu. Bununla beraber bitarafane hareket etmiş olmak için buna bir kayt koyduk ve muhtemel bir itirazı derpiş ettik. Bu itiraz, kusurun adli ve hukuki sistemde değil, cezanın infazı usulünde oldu. ğunu ileri sürmekten ibaret bulunuyor idi. Diğer bir ifade ile cezanın kanunen ve adli çhetten herkes için müsavi tayin edilntiesi prensibine dokunulmamakta, eğer penoloji sahasında dokunulmuş bir cihet var ise o da cezanin infazı usulünden ibarettir. Bu itibarla bunu tashih etmek kâfidir, denilmekte idi. Fakat yukanda gördük ki bunun tashihi ancak cezanın müsaviliğgnin daha başlanģı̧tan itibaren, cezanın adli makamlarca berkes icin müsavi olarak tayini keyfiyetinin ortadan kaldırılmass ve adli makamlarn cezayı suça göre değilde ferde göre tayin etmeleri ile mümkündür.

Hakikaten, bugün artık aynı suç için, gerek mahiyet gerek, müdde: bakımınclan aynı cezalann verilmesi icab edeceğ: likri kabili müdafaa değildir. Mevcut durumun tashihi için bu keyfjyetin kabulü icab edeceği ve ancak bu noktadan hareket ile mevcut durum islâh olunabilece ̛̛̆ teslint olununca. hemen hemen her şeve yeni baștan başlamak icab ettiğini ve her halde isi temelinden ele almak gerektiğini de itiraf etmek lâzımdır. Bu suretle klàsik s'stemin să̆lam bir dayânăğ kalmamıṣ bulunmaktadır. Iste meselenin halihazır durumu budur.

Italyan nrektebi bu curum karșisinda ve mevcut mektebin hasıl 
ettiği bu gayri müsait neticelere bir tepki olarak doğmuştur. Bakahım şimdi bu mektep'in ne teklif ettiğini görelim:

Bütün Italyan mektebini, tek bir cümle ile hülâsa etmek mümkündürr: Italyan mektebi, determinizi mihrak noktası olarak alan ve bu aksiyona istinad ederek sosyal hâdiseleri muhakeme eden ve neticeler çkaran bir mantık sistemidír. Sosyolojiye istinat ettigini zanneden bu mektep hakikatte, tamamen- biraz dikkat edildikte- kolaylıkla farkedil. mesi işten bile olmayan bir sylogisme'e istinad etmektedir.

Sosyolok'luk, her şeyden evvel hâdiselerin müşahade ve tesbitini, tarihin mahsulü bulunan ve sosyal, psikolojik kanunlan idare eden fikirlerin birer vakıa olarak kabulünü icab ettirir. Halkın şuur ve vicdanının esasın teșkil eden bu fikirlerarasında ise felsef ceryanlann tahripkâr tesirlerine ve inanışlardan bir çoklannın kayboluşuna rağmen halen dimdik ayakta kalmı̣ bulunanlar mevcuttur. Bunlar arasında "mesuliyet" diye bir şeyin mevcudiyetine olan inanış ile, manevi serbesti (muhtariyet) diye bir şeyin mevcut bulunduğuna dair olan fikir de mevcuttur. Herkez tarafından suçlulara karşı cezai mahiyette tedbirlere baș vurulmasına mukabil akıl hastalarına karşı sırf önleyici mahiyette tedbirlere baş vurulabileceği fikrinin kabul edilmesi bu esasa istinad etmektedir. Bahusus sosyolok olan bir cezacı bu hisleri, fikirleri ve onlarn kriminoloji üzerindeki tesirlerini nazàra alamamazlık edemez. Bütün bunlan kaldınp atacak bir ceza makanizması kitlelerin şuur ve düșünüșüne o derece aykırı gelecektirki, böyle bir sistemi mevkiitatbike koymak dahi mümkün olmayacaktır. Tamamen mücerret olarak toplumdaki müşterek şuuru nazara almaksızm bir kiriminoloji inşa etmeğe kalkmak, Sieyes'in siyasi müesseseler bahsinde yapmak istediği gibi hareket etmek olur. Bu felsefi doğmatizmin, artrk zamanı geçmiş bulunmaktadır. Bununla beraber Italyan mektebinin teklif ettiği, bundan başka bir şey değildir. Filhakika bu mektebi şu dar düşüince çerçevesi içine kapanıp kalmıs bulunmaktadır.

Insan sevkitabiilerini ve manevi hasselerini idareden acizdir. İnsanda suç ya potolojik yapısının (Lombưjonun düşünüșü), yahutta içinde yaşadığı içtimai muhitin ve hayatına hakim olan ekonomik şartlanıı (ferrinin görüșï), mukadder bir neticesidir; bu itibarla, ceza ne bir müeyyip de ne de cemiyetin takbihi mahiyetini taşyabilir. Bir kimse ancak yapıp yapmanakta serbest olduğu bir fenahğı yaptığından dolayı cezalandırılabili* veya takbih olunabilir. Ceza artik tipkı tehlikeli bir hayvan veya bir deli karşısında alınan muhafaza tedbirleri gibi, umumi bir mü- 
dafaa ve emnjyet tedbirinden başka bir şey değildir. Veya daha doğrusu. bir fenahğın tekerrürüne veya zuhuruna mani olmak için. artık tenkili tedbirlere değil, önleyici tedbirlere başvurulmak icab edecektir. Suçludá ise tehlikeli olan ve cemiyet için bir tehlike teşkil eden cihet onun işleyip bitirmiş olduğu suç değil, şahsiyeti, onu her an yeni yeni suçlar işletebile. cek olan tabłyatudır? Tehlikeli cihet onun için de bulunup her an, adamı öldürmek, hrrsızlık, ahlak ve daba mugayeret şeklinde, kendini açığa vur. mağa hazır olan gizli temayüldür. Bir suç işlenip bittikten sonra, bir suça cezalandırılmıs veya cezalandırılmamış, bundan cemiyet için ne gibi bir fayda hasıl olabilir. Olan olmuş, mazarrat meydana gelmiştir. Bundan sonra olsa olsa, ancak vukua gelmiş olan zarar tazmin ettirilmek imkân yoktur. Ancak bunun bir defa daha vaki olmasına mani olmak mümkündür ve ehemiyetli olan da budur. Bunun için de yaplacak şey suçluda ki suçluluk tamayülüne hakim olmak ve bu temayülü ortadan kaldırmak veya, eğer ekseri hallerde olacağı gibi, bu mümkün görünmüyor ise nasıl bir vebah veya tehlikeli bir hayvanın vücudu ortadan kaldınlmak icap eder ise öylece, stiçlunun da bizzat kendisini ortadan kaldırmak lâzımdır. Bu itibarla suçlı: hakkında tedbir alırken, onun zarar verme imkânı ve bu imkânın neticesi olarak telkin ettiği korku (ltalyanlann dediği gibi failin "tehlikeliliği") nazara alınmalı ve eger islah olmasına imkân var ise islahını saghyacak tedbirlere baş vurmalı yoksa ifnası cihetine gidilmelidir. İște kısaca Italyan mektebinin düşüncesi bundan ibarettir.

Bu düşünce karşısında suç, o zamana kadar klâsik mektebin ona atí1 ettiği değerden tamamiyle başka bir değer iktisap etmektir. Suç artık ceza mevzu'u olmaktan çımakta ve artık, cezayı müstelzim bir fiil teșkil etmemektedir. Ancak suçludaki suç işleme temayülüne, tehlikeliliğe bir bir işaret teşkil etmek bakımından ehemmiyeti haizdir. Cezayı müstelzim fiil yok, fenalık yapamayacak hale sokulmak icab eden kimseler vardır ve suçta bu kimseleri tayine medar olmaktadır. Suçun değeri bir alâmet ol. maktan ibarettir. Isşte bu suretle suçlu mefhumu ve, sistemin ruhuna uy. gun bir ifade ile, suçlunun tetkiki, suç adı verilen hukuki mefhum yerine kajm olmaktadır. Suçlar tasnife tabi tutulacak yerde suçlular tasnife tâbi tutulmalıdır. Ceza suçun sözde ağırlığına uydurulacak yerde suçlunun ta. biatna uydurulmalıdır. Artik suçtan değil, suçludan bahsedilmek ve bunlardan birinin her zaman diğerinjn delili olamayacağı kabul edilmek lâzım. dır. Bunlardan biri bir vakıa, dișeri ise psikolojik bir faktördür. Bu iki mefhumun muhakkak surette birbirine tekabül etmesi icab etmez. Suçluluk muhakkak surette suça vücut verir; fakat suç muhakkak surette suçluluğun mahsulüi değildir. Hakikaten ilmi olan bir sistemin her șeyden evvel bu ikisini sarih surette bir birinden ayrdetmesi jcab eder. 
Her halde, bundan böyle bütün suçlulan birbirine ircai mümkün olmayan iki guruba ayırmak icab eder: islâhı kâbil olanlar ve olmayanlar. Bu sonuncular, ceza ile (refractaire â la peine) uslanmayanlar, yani gayri kabili islâh olanlar, cemiyet hayatı için yapılmamış olmayn cemiyete mal edilmeleri mümkün değildir. Yaplacak şey bunlan zarar veremiyecek hale sokmak, yani ortadan kaldırmak veya tasfiye etmektir. Diğerlerine gelince bunlan da karakterlerini dikkatle tetkik etmek suretiyle muhtelif tali guruplara tefrik etmek icab eder. Zira hepsinin islâhi kabil olduğu kabul edilmekte ise de, hepsinin aynı vasitalarla islâhı mümkün değildir. Eğer suç Lombrozonun iddia ettiği gibi, bilhassa potoloji bir vakıa ise, her hangi çeşit suçluluk illeti mevzubahis ise, onun tedavisine uygun gelecek cezayı (eğer buna hâlâ ceza adı verilebilïr ise) seçmek lâzmdır. Böylece tam ve hakikî mânada, bir ferdileştirmeye vanlmış olmaktadır. Öyle bir ferdileştimeki işlenmiş bulunan fïle göre vaki olmamakta ve dolayısiyle mes'uliyet derecesinden sarfı nazar edilmektedir. Zira mes'uliyet işlenmiş muayyen bir fiilj tazammun eder burada ise fill mevzu bahis değildir. Buradakj ferdileştirme şahsın karakterine, gizli ve virtüel suçluluğuna. göre vâki olup her suçlunun, manen islâhı için gerekli hưsuslara cezanm uydurulmasina gayret etmektedir. Iște Italyan mektebi böyle yeni bir ferdileştirmenin lüzumunu ileri sürmektedir.

Muhakkak, böyle bir ferdileştirmenin iyi bir ferdileştirme olduğuna şüphe yoktur; ve bugün artık bunun pratik neticelerinin kabul edilmesin. den başka yapacak bir şey kalmamıștır. Yalnız, Italyan mektebinin, korkunç denilebileceğini sandığımı taraf, şekilprest bir muhakemesi, mücerret, radikal, ve eğjimez bir mantığı oluşudur; öyle bir mantık ki, hukuk sahasinda çok mantki ve geometrik bir zihniyet hususunda ekseriya vaki olduğu gibi, tersine de dönebilir. Ve şüphe yoktur ki, daha evvelcè söy. lenmiş olmašna rağmen, faydasına binaen bir daha tekrar edelim, lhtilâllerin mantıkla yapıldığına ve ihtilâlleri mantığın yaptiğina inanmiyor değiliz. Çünkü kitlelerin sade düşüncesine ve yğ̆ın psikolojisine en iyi cevap veren şey mantktır. Fakat yine şüphe yoktur ki cemiyet, normal halde, mantıkla yaşamamaktadır. Bilâkis, Cemiyet realitelerle doludur. Realiteler ise basit değil, mürekkeptir; bu mürekkeplik, onlann muhtelif menfaatlerin uzlaşması ve nihayi muhasalası olmalanndan ileri gelmektedir. Bu hal realitelerin düz bir hat ve mantrk gibi bir bütün saylmasına mânidir. Realite, bir bütǜn değildir. Sadece mücerret, doğmatik veya radikal ( $k i$ bu ikisi ayni şeydir) bir düşünüş, şekli realiteyi bir bütün haline sokmak ve bu şekilde muhafaza etmeğe çalışır.

Şimdi Italyan mektebinin syllogistiomen prensiplerinin ne netice- 
lere müncer olacağını görelim: Bu prensipler şu iki neticeye müncer ốmaktadır. Birincisi, suç işlemiş olmalarına rağmen bir çoklarının cezadan muaf tutulması, ikincisi de, bunun aksine, hiç bir suç işlememiș kimselerin suç işlemesin diye, evvelden cezalandırılmalan. Bu hal suçlułarın iki yeni guruba aymılmasın icab ettirmektedir. Birinci gurup, cezalandiri. mayacak suçlular gurubu. Bu gurup sahte suçlular gurubudur. İkinci gurup ise, suçlu olmadikları halde cezalandırlmalan icab edenler gurubu. Bu gurubu șüpheli kimseler teşkil etmelitedir.

Birinci gurubu, yalancı suçlular gurubunu ele alalım; bunlar,- insaniyet için çok hayırlı bir keyfiyettirki pek kalabalıktırlar. Bu gurupta bulunan suçlular için ișledikleri suç anormal bir hâdise teşkil eder. Bir emniyeti suiistimal veya hattâ bir adam öldürme cürmü işlemiş öyle kimseler var dır ki bu fiifleri hangi şartlar altında işlediklerine bakıldıkta görülmektedir ki bunların isslenmesinde bu kimselerin tabiatlannın hiç bir rolü olmayıp bu kimseler hâdiselerin tesiri ile bu fiilleri işlemeye sürüklenmişlerdir ve bunlarda bir suç temayülü mevcut olmadığından veya henüz bulunmadı. ğından emin olunabilir, böyle bir temayülü bu gibi kimselerde belki sonradan hapishane doḡurabilecektir.

Hapishaneye girmeden suç işlemeye tabiiaten bir temayülleri yoktur. Bu gibi kimselerin tekrar bir suç işlememeleri için ceza tamamiyle lüzumsuz olduğu gibi, hattâ bunlara ceza verilmesi tehlikeli de olabilir. Ortada ne tedavisi gereken bir hastalık, hattâ ne de islâh ve terbiye edil. mesi gereken bir ruh mevcuttur; olsa olsa bazı alıskanlıklardan vaz geçił. meye veya bir muhit değişikliğini icbar etmek icab edebilir. Cezalandırmağa ne gibi bir lúzum olabilir? Fithakika ceza artık cezalandırmayı yani vukubulmuş olan fenalığ istihdaf ełmemekte, vuku bulacak olan fenalığa mani olmay, yani tedavi etmeyi veya zararsı hale getirmeyi tehlikeliyi bertaraf etmeyi istihdaf etmektedir. Bu gurup suçlularm mevzu bahis olduğu yerde ise vukuuna mani olunacak bir tehlike mevcut değildir. Tedaviye muhtaç bir şey olmadığ gibi, tavsiyesi icab eden bir tehlike de mevcut değildir. Bu ițbarla, bu suçlular için ceza lüzumsuz ve dolayısiy. le haksız olacaktır. İste bu gurup yalancıktan suçlular, sözde suclular, cezalandırılmamaiarı gereken suçlular gurubunu teșkil eder. Bu hal göstermektedir ki zahiri suçluluğu diğerinden deruni (hakiki), asıl ehemmiyeti olan suçluluktan ayırmaya çok dikkal etmelidir; birincisi zahir: göz le görünen bir hâdisedir, maddi bir fiil șeklinde tezahür etmektedir; böyle bir tezahür muhakkak surette insanın tabiatin mahsulü olan suçluluk temayüiüne térabül edecektir; Apriori böyle bir şey söylenemez. Böy- 
bir tezahür, tamamiyle geçici hiç bir ihtimali bulunmayan had bir kriz de olabilir. Hakiki manada suçluluk, cezalandınlması yani icab eden suçluluk müzminleşmiş, şahsın psikolojisinin bir hususiyeti haline gelmiş ve bu psikolojinin bir tezahürü olan ve dolayısiyle daima tekrar etmesi ihtimali bulunan suçluluktur. $O$ halde, dahili, hakikî bir suçluluğu olmayan suçlulan bir tarafa bırakabiliniz: böyle suçlulann bahis mevzu'u olduklan hallerde bir suç vakıası mevcuttur. (Hakikî) bir suçluluk mevcut değildir. Ortada hukuki bir suçluluk bulunmaktadır. Karşı tarafta ise diğer gurup vardır; ve işin ehemmiyet arzettiği nokta da burasıdır. Burada, henüz hukukî suçluluk mevcut olmamakla beraber tabii suçluluk mevcut bulunmak: tadır. Henüz bir suç vakıası vukubulmuş, fakat hakikì suçluluğun mevcudiyeti sabit olmuştur. Bu gurubu suçlu olmamakla beraber cezaland. nImalan icab edenler, yani şüpheliler sınıfı teşkil eder. Mevzubahis olan, cemiyeti, işlenecek suçlara karşı korumak olduğuna göre, suçlunun, henüz suçunu işlememiş iken yakalanması icab edeceği itiraz kabul etmez bir hakikattir. Bir ev sokaktan gelip geçenlerin üzerine yıkılmak tehlikesi arzettiğ: takdirde, tedbir almak için bir kazanın vukubulması beklenmez; yine bir akıl hastası da tehlike arzetmeye başladığı takdirde, yakalamp. henüz bir kazaya sebeb olmadan bir yere kapatılır. Ehli bir hayvanda, bir hastalıktan şüphe edildiği ve bu hastalık ona yaklaşanlar için tehlikeli olacağı takdirde, hastalığın baş göstermesi beklenmeden bu hayvan tutulup bir yere kapatılır veya öldürülür. Böyle olduğu halde, fenalık içinde doğmuș, fenalık için de büyümüș, bir türlü cemiyete mal olmamış ve olmasına da imkân bulunmayan temayülî suçlu mevzubahis oldukta ne. den dolayı tereddüt edilmektedir? 